\title{
Liever kwaliteit van leven dan zelfredzaamheid
}

\author{
Evelien Tonkens
}

Published online: 31 October 2018

(C) Bohn Stafleu van Loghum is een imprint van Springer Media B.V., onderdeel van Springer Nature 2018

De decentralisaties van het sociale domein brengen professionals en burgers dichter bij elkaar. Dat is een grote verworvenheid. Probleem is echter dat zelfredzaamheid daarbij het leidende ideaal is. Evelien Tonkens pleit voor het verlaten van zelfredzaamheid ten gunste van kwaliteit van leven.

\section{Papieren succes}

De decentralisaties hebben sociale professionals letterlijk dichterbij de burger gebracht, vaak met succes. Uit ons vierjarig onderzoek naar de interactie tussen wijkteams en cliënten blijkt dat beide partijen dat waarderen. In plaats van opgeknipte dienstverlening met telkens inloggen, doorklikken, doorschakelen en verloren raken is het fijn om echte mensen te spreken die je problemen in onderlinge samenhang bekijken.

Zelfredzaamheid is daarbij het leidende ideaal. Op papier is dat een groot succes. Een evaluatie van Meedoen werkt in Amsterdam uit 2016 berekende bijvoorbeeld dat $67 \%$ van de deelnemers na zes maanden op ten minste één domein meer zelfredzaam is geworden.

Maar wat is zelfredzaamheid? De veelgebruikte zelfredzaamheidsmatrix geeft de term drie heel verschillende betekenissen. Ten eerste: jezelf redden, zelf doen. Ten tweede: zelf hulp vragen in je eigen netwerk. Ten derde: professionele hulp vragen (om in een later stadium het alsnog zelf te doen of het netwerk te vragen).

Deze bijdrage is gebaseerd op het boek De verhuizing van de verzorgingsstaat van Femmianne Bredewold et al., dat in september is verschenen bij uitgeverij Van Gennep.

\section{E. Tonkens $(\bowtie)$}

Universiteit voor Humanistiek, Utrecht, Nederland e.tonkens@uvh.nl
Neem bijvoorbeeld het domein Lichamelijke gezondheid, een van de zes domeinen van de zelfredzaamheidsmatrix. Je bent 'niet zelfredzaam' volgens deze matrix wanneer je je niet laat behandelen voor een medische aandoening. Wanneer je je wel laat behandelen, maar weinig therapietrouw vertoont, scoor je als 'beperkt zelfredzaam'. 'Voldoende zelfredzaam' ben je als je behandeltrouw toont en 'volledig zelfredzaam' wanneer je 'geen directe of voortdurende medische problemen' hebt. Kortom: naarmate je je beter laat helpen, ben je zelfredzamer. Zelfredzaamheid is een dermate breed opgerekt begrip dat iedere stap die een cliënt maakt als toename van zelfredzaamheid te scoren is. En dus kan beleid op papier succesvol zijn, bijna ongeacht wat er in de praktijk gebeurt.

\section{Weerbarstige praktijk}

In ons onderzoek zagen wij dat onder de vlag van zelfredzaamheid inderdaad alle drie dingen gebeuren. Het vaakst zagen we het derde: meer professionele hulp. Wij hebben honderden keukentafelgesprekken geobserveerd. Professionals deden steevast een poging om het netwerk in te schakelen. Maar slechts drie van de 66 keukentafelgesprekken waarin aanspreken van het netwerk verwacht mocht worden, leidden daadwerkelijk tot een grotere inzet van het netwerk. In die andere 63 situaties waren er geen naasten (meer) of de naasten waren al (bijna) overbelast, woonden te ver weg of kampten zelf met problemen. Of ze waren zelf (mede) oorzaak van de problemen van de hulpvrager. Het kwam ook voor dat vragen van (meer) hulp het precaire evenwicht in een relatie met zoon of zus zou verstoren. En buren of vrienden om hulp vragen, roept de angst op dat ze zelf iets soortgelijks nooit kunnen terugdoen. En dus bleek na zorgvuldig uitvragen dat er vaak toch professionele hulp nodig was. Niettemin kunnen professionals in alle eerlijkheid op 
papier aangeven dat er sprake is van een toegenomen zelfredzaamheid, dat immers zoveel verschillende betekenissen heeft.

\section{Kwetsend}

Dat geeft professionals veel ruimte. Mooi, want dat is ook een van de doelen van het huidige beleid. Toch is het problematisch dat zo'n inhoudsloos opgerekt begrip zo leidend kan zijn. Want hierdoor kan het beleid niet door de praktijk worden gecorrigeerd. Straks 'blijkt' uit nog veel meer evaluaties dat de zelfredzaamheid van Nederlanders sinds de decentralisaties sterk is toegenomen. De regering kan er mooie sier mee maken en betogen dat mensen elkaar dus veel meer kunnen helpen dan gedacht. Ze kan er ook verdere bezuinigingen mee legitimeren. Waardoor professionals nog harder moeten rennen om mensen toch te kunnen helpen.

Bovendien kunnen hoge verwachtingen van het netwerk schade aanrichten. Want wijkteamleden moeten doorvragen: 'Kan je zoon of dochter niet wat vaker komen? Kun je de buren niet vragen?' En, als mensen niet meteen iemand weten die kan helpen: 'Wie was er op je laatste verjaardag? Met welke ouders praat je wel eens op het schoolplein?' Daarmee belasten ze mensen met schuld- en schaamtegevoelens. Een eenzame alleenstaande moeder werd bijvoorbeeld gedwongen ouders van een vriendje om hulp te vragen. Die ouders kende ze nauwelijks en het was ook niet verwonderlijk, maar wel beschamend en kwetsend dat deze mensen afwijzend reageerden.

De nabijheid van de keukentafel is een grote verworvenheid. Maar gemeenten doen er goed aan professionals met een breder ideaal op pad te sturen. Niet zelfredzaamheid, maar kwaliteit van leven zou centraal moeten staan. Zelf doen en het netwerk aanspreken kan daarbij behulpzaam zijn, maar kan evengoed schaden. Hoe kan uw levenskwaliteit verbeteren, en wat kunnen naasten en sociale voorzieningen daaraan bijdragen? Dat zou de centrale vraag moeten zijn waar gemeenten professionals mee op pad sturen.

\title{
Gemeenten en thuiszorgmedewerkers zouden meer oog moeten hebben voor mantelzorgers
}

\author{
Mirjam de Klerk · Alice de Boer · Inger Plaisier
}

Published online: 5 November 2018

(C) Bohn Stafleu van Loghum is een imprint van Springer Media B.V., onderdeel van Springer Nature 2018

\begin{abstract}
Mensen die zorg en ondersteuning krijgen, ontvangen die meestal van mensen uit hun eigen sociale netwerk. Ongeveer een derde van de Nederlanders geeft mantelzorg. Welke ervaringen hebben zij met de Wmo? Er zijn indicaties dat de gemeenten en zorgmedewerkers nog onvoldoende oog voor hen hebben.
\end{abstract}

\footnotetext{
M. de Klerk $(\bowtie) \cdot$ A. de Boer · I. Plaisier

Sociaal en Cultureel Planbureau, Den Haag, Nederland

m.de.klerk@scp.nl

A. de Boer

Vrije Universiteit Amsterdam, Amsterdam, Nederland
}

\section{Welke taken hebben gemeenten als het gaat om mantelzorg?}

Uitgangspunt van het beleid is dat mensen meer voor elkaar zouden kunnen zorgen en dat iemand die ondersteuning nodig heeft eerst in eigen kring nagaat of hij die daar kan krijgen. Gemeenten dienen ook te voorkomen dat mantelzorgers overbelast worden door hen zo nodig mantelzorgondersteuning te bieden. Dat kan bijvoorbeeld door mantelzorgers te betrekken bij het onderzoek naar de hulpvraag van de cliënt of door zorgmedewerkers aan te moedigen om niet alleen naar de cliënt te kijken, maar ook naar zijn of haar naasten. Dit klinkt mooi, maar de praktijk is weerbarstig. 